BEATA LORENS* - RZESZÓW

\title{
DZIALALNOŚĆ SODALICJI MARIAŃSKIEJ W KOLEGIACH BAZYLIAŃSKICH NA ZIEMIACH RZECZYPOSPOLITEJ W XVIII I XIX WIEKU
}

Sodalicje Mariańskie zakładane w szkołach jezuickich okresu nowożytnego stały się przedmiotem zainteresowania historyków Kościoła i historyków wychowania. Ci pierwsi przyglądali się im jako stowarzyszeniom religijnym charakterystycznym dla okresu potrydenckiego, zaś ci drudzy poświęcali im uwagę z racji zakładania i funkcjonowania kongregacji w kolegiach kształcących młodzież świecką. Najczęściej o Sodalicji Mariańskiej pisano przy okazji prezentowania szkolnictwa jezuickiego, a jednak jak skonstatował Marek Inglot nie wszystkie aspekty funkcjonowania kongregacji zostały wyjaśnione i opisane ${ }^{1}$.

Niniejszy tekst nawiązuje do działalności Sodalicji Mariańskiej w kolegiach prowadzonych na wschodnich kresach Rzeczypospolitej przez zakon bazyliański. Oparty został na źródłach rękopiśmiennych bezpośrednio związanych z funkcjonowaniem kongregacji studenckich, przechowywanych $w$ archiwach ukraińskich i polskich. Należały do nich pozwolenia na zorganizowanie sodalicji wydawane przez władze kościelne, księgi rejestrujące nazwiska członków oraz skład władz towarzystwa wyłanianych podczas elekcji, spisy przedmiotów lub też zawartość bibliotek należących do kongregacji, dochody oraz wydatki ponoszone w ciągu roku przez sodalisów. Pośrednio o działalności Kongregacji Mariańskiej zaświadczały inwentarze monasterów bazyliańskich, zawierające opis pomieszczeń przeznaczonych na potrzeby uroczystości sodaliskich, czy też przedmiotów (ołtarz, obrazy, świece) wykorzystywanych w ich trakcie. Wiadomości na temat działalności sodalicji odnaleźć też można w aktach szkolnych, informujących o aktywności profesorów i uczniów podejmowanej w ramach procesu dydaktyczno-wychowawczego. Ważnym źródłem informacji stały się również raporty wizytatorów szkolnych, którzy z ramienia Komisji Edukacji Narodowej wizytowali kole-

* Beata Lorens - dr historii, adiunkt w Instytucie Historii Uniwersytetu Rzeszowskiego.

${ }^{1}$ Zob. M. Inglot, Kongregacje (Sodalicje) Mariańskie w szkołach jezuickich od XVI do XVIII wieku. (Postulat badawczy), w: Historia. Spoteczeństwo. Wychowanie. Ksiega pamiatkowa dedykowana Profesorowi Józefowi Miąso, Pułtusk-Warszawa 2004, s. 277. 
gia bazyliańskie funkcjonujące na ziemiach pozostających po 1773 r. przy Polsce. Bardzo rzadko występującym, ale niezwykle interesującym źródłem wiadomości o działalności sodaliskiej były pamiętniki i dzienniki prowadzone przez bazylianów. Analiza tych źródeł pozwoliła na przybliżenie niektórych problemów funkcjonowania Sodalicji Mariańskiej w kolegiach bazyliańskich w XVIII i w XIX w.

Bazylianie (Ordo Sancti Basilii Magni), jedyny zakon męski w Kościele unickim, prowadzili działalność oświatową obok pracy duszpasterskiej i misyjnej. Przy monasterach tworzono trzy rodzaje szkół: wewnętrzne studia zakonne często łączone z seminarium dla księży diecezjalnych, publiczne kolegia oraz szkoły parafialne. Przedmiotem poniższych rozważań będą średnie szkoły publiczne. Pierwsza placówka oświatowa dla młodzieży świeckiej prowadzona przy monasterze bazyliańskim powstała jeszcze w XVII w., ale ich rozkwit przypadł na następne stulecie. Bazylianie w drugiej połowie XVIII w. zajmowali w Rzeczypospolitej trzecie miejsce, po jezuitach i pijarach, w ilości zorganizowanych średnich szkół publicznych. Do 1772 r. działało dziewięć bazyliańskich placówek oświatowych dla młodzieży świeckiej, zaś po kasacie zakonu jezuitów utworzono dalszych 11 szkół prowadzonych przez zakon św. Bazylego Wielkiego. Pod względem organizacji, programu nauczania oraz procesu dydaktyczno-wychowawczego szkoły bazyliańskie oparte były na wzorcach jezuickich ${ }^{2}$.

Bazylianie czuli się przygotowani do prowadzenia działalności edukacyjnej, która była przez nich postrzegana jako zaszczyt i wyjątkowe zadanie. Jak stwierdził jeden z bazylianów: ,nic bardziej sławy naszej pomnożyć nie może nad usługi nasze w uczeniu szkół publico świadczone"3. Po kasacie zakonu jezuitów w 1773 r. bazylianie zaproponowali Komisji Edukacji Narodowej przejęcie kolegiów jezuickich wraz z budynkami i innymi dobrami. Plany te popierał nuncjusz Giuseppe Garampi, ale opinia Komisji była niekorzystna dla bazylianów. Postanowiono, że o losie poszczególnych kolegiów pojezuickich decyzje będą podejmowane nie gremialnie, ale pojedynczo. Ostatecznie bazylianom przekazano trzy szkoły: w Barze, Ostrogu i Owruczu ${ }^{4}$. Z propozycją poprowadzenia nauki w kolegiach jezuickich na ziemiach polskich zajętych przez Austrię wystąpił zwierzchnik

${ }^{2}$ M. Pidłypczak-Majerowicz, Bazylianie w Koronie i na Litwie. Szkoły i ksiażki w działalności zakonu, Warszawa-Wrocław 1986, s. 35-37, 44-48. Do 1772 r. zorganizowano kolegia we Włodzimierzu Wołyńskim, Żyrowicach, Hoszczy, Szarogrodzie, Buczaczu, Lubarze, Humaniu, Malejowicach (konwikt szlachecki) i Borunach, zaś w latach 1773-1795 utworzono szkoły w Barze, Berezweczu, Kaniowie, Ostrogu, Owruczu, Podubisiu, Ławrowie, Drohobyczu, Świerżeniu, Tołoczynie i Żydyczynie. Szkoła w Hoszczy przestała istnieć po oddaniu bazylianom kolegium pojezuickiego w Ostrogu. Autorka wymieniała jeszcze dwie szkoły bazyliańskie w Warszawie i Supraślu, jednak pod koniec XVIII w. one nie działały lub miały status szkoły parafialnej.

${ }^{3}$ Lwowska Narodowa Naukowa Biblioteka Akademii Nauk Ukrainy im. W. Stefanyka (dal. cyt. LNNB), f. 3 (zbiór rękopisów bazyliańskich), sp. 649/1-Materiały z kanonicznych wizytacji klasztoru i szkoły w Buczaczu 1755-1781, 1813-1852, k. 13v.

${ }^{4}$ Protokoły posiedzeń Komisji Edukacji Narodowej 1773-1785, opr. M. Mitera-Dobrowolska, Wrocław-Warszawa1973, s. 14, 30; M. Miterzanka, Działalność pedagogiczna Adama ks. Czartoryskiego generała ziem podolskich, Warszawa-Lwów 1931, s. 172-175; T. Mizia, Szkoły średnie Komisji Edukacji Narodowej na terenie Korony, Warszawa 1975, s. 25-28, 31; Pidłypczak-Majerowicz, Bazylianie w Koronie i na Litwie, s. 39-40. 
prowincji polskiej (zwanej też koronną lub ruską) Onufry Bratkowski. Wysunął pomysł, aby bazylianie przejęli prowadzenie szkół pojezuickich w Jarosławiu, Samborze i Stanisławowie. Sprawa nie doszła wówczas do skutku głównie wobec wniosku bazylianów, aby to rząd austriacki ponosił koszty ich utrzymania ${ }^{5}$.

Sodalicja Mariańska była ważną formą aktywizacji religijnej, stosowaną w kolegiach zakonnych. Skupiała ona młodzież szkolną wyróżniającą się pobożnością i dobrymi wynikami w nauce. Członkostwo w organizacji świadczyło o przynależności do elity uczniowskiej. Celem sodalicji było pogłębianie własnej pobożności, ale również miała ona aspekt społeczny, bowiem poprzez organizowane nabożeństwa, elekcje władz, gospodarowanie funduszami wdrażano do aktywnego uczestnictwa w życiu publicznym. Przynależność do kongregacji młodzieży pochodzącej z różnych grup społecznych kształtowała zrozumienie potrzeb społeczeństwa. Sodalisi mieli poprzez solidną naukę podnosić poziom naukowy szkoły, włączać się w nauczanie katechizmu, uświetniać uroczystości kościelne, opiekować się chorymi i ubogimi. Działalność sodalicji stanowiła ważny czynnik wychowawczy i przygotowywała młodzież do życia publicznego ${ }^{6}$.

Swój początek Sodalicja Mariańska wzięła w rzymskim kolegium jezuickim w 1563 r. Jej założycielem był kleryk jezuicki Jan Leunis. Celem wspólnoty było osiągnięcie cnót chrześcijańskich poprzez propagowanie pobożności maryjnej. W 1584 r. papież Grzegorz XIII na mocy bulli „Omnipotentis Dei Salvatoris nostri” ustanowił przy kościele Il Gesu pierwszą Kongregację, czyli Sodalicję pw. Zwiastowania NMP, nazywaną Prima Primaria i pozwolił na dalszy rozwój tego typu stowarzyszenia przy kolegiach jezuickich na całym świecie, podporządkowując je jednocześnie Kongregacji rzymskiej. Zatwierdził ustawy sodalicji oraz nadał jej odpusty ${ }^{7}$. Dla potrzeb sodalicji generał zakonu o. Klaudiusz Aquaviva ułożył statut, który był w XVI-XVIII w. wielokrotnie wydawany w Rzeczypospolitej $^{8}$. Miejsce i rolę kongregacji w kolegiach jezuickich określała ustawa szkolna Towarzystwa Jezusowego z 1599 r., gdzie wśród obowiązków nałożonych na rektora kolegium wymieniano też staranie o założenie Sodalicji Mariańskiej9.

Pierwsza kongregacja na ziemiach polskich została erygowana $\mathrm{w}$ kolegium jezuickim w Braniewie w 1571 r. Według ustaleń Jerzego Flagi w 1772 r., a więc tuż przed kasatą Towarzystwa Jezusowego, na terenie Rzeczypospolitej funkcjo-

${ }^{5}$ W. Chotkowski, Redukcje monasterów bazyljańskich w Galicji, Kraków 1922, s. 76.

${ }^{6} \mathrm{R}$. Pelczar, Działalność oświatowo-kulturalna jezuitów $w$ diecezji przemyskiej $w$ XVI-XVIII wieku, Przemyśl 1999, s. 78-79; S. Kościelak, Jezuici w Gdańsku od drugiej połowy XVI do końca XVIII wieku, Gdańsk 2003, s. 160.

${ }^{7}$ Historya kongregacyi Maryańskich, „Sodalis Marianus”, 1 (1896) nr 1, s. 2-3; E. Kabat, Sodalicje mariańskie w diecezji tarnowskiej, „Rocznik Tarnowski”, 1997/98, s. 155.

${ }^{8}$ Inglot, Kongregacje (Sodalicje) Mariańskie w szkołach jezuickich, s. 280.

${ }^{9}$ Ratio atque insitutio studiorum SJ czyli Ustawa szkolna Towarzystwa Jezusowego (1599), opr. K. Bartnicka, T. Bieńkowski, Warszawa 2000, s. 47. Niech dołoży starań, by Zgromadzenie Zwiastowania Najświętszej Maryi Panny zostało przeniesione z Kolegium Rzymskiego do jego kolegium; ten kto się do niego nie zapisze nie powinien zostać przyjęty do akademii, w której odbywaja się ćwiczenia z literatury; chyba że sam rektor z natchnienia Pana postanowi inaczej. 
nowało 71 bractw studenckich, czyli sodalicji ${ }^{10}$. Do 1751 r. do Sodalicji Mariańskiej przyjmowano wyłącznie młodzież męską, zaś po tym roku do grona sodalisów włączano również dziewczęta ${ }^{11}$.

Spośród szkół prowadzonych w XVIII i na początku XIX w. przez bazylianów udało się odnaleźć informacje o funkcjonowaniu Sodalicji Mariańskiej w kolegiach w Buczaczu, Hoszczy, Humaniu, Lubarze, Szarogrodzie, Włodzimierzu oraz w szkołach przejętych przez bazylianów po kasacie Towarzystwa Jezusowego w Barze, Ostrogu, Owruczu i Poddubisiu, a więc łącznie w 10 placówkach spośród 20 działających we wskazanym okresie.

Jedną z kongregacji o najstarszym rodowodzie w kolegiach bazyliańskich była Sodalicja Mariańska działająca przy szkole w Buczaczu. Sama placówka oświatowa w tym mieście została uruchomiona na mocy fundacji starosty kaniowskiego Mikołaja Potockiego z 1754 r. Było to 5-klasowe kolegium, złożone z infimy, gramatyki, syntaksy, retoryki i poetyki. W 1773 r. utworzono klasę szóstą - filozofię. Czas edukacji obejmował wówczas 8 lat ${ }^{12}$. O działalności Sodalicji Mariańskiej w kolegium buczackim świadczyły zachowane księgi, dokumentujące jej funkcjonowanie, przechowywane w Lwowskiej Narodowej Naukowej Bibliotece Akademii Nauk Ukrainy im. W Stefanyka. Były to: księga zapisów elekcji władz kongregacji z lat 1758-1836 oraz księga przychodów i rozchodów z lat 1774$1880^{13}$. Ponadto wzmianki na temat działalności sodalisów znajdowały się w dzienniku prowadzonym w klasztorze w okresie 1750-1770, a zapoczątkowanym przez o. Jana Hieronima Nereziusza, w aktach szkolnych z lat 1758-1780 oraz inwentarzu klasztornym z 1769 r. spisanym przez rektora Innocentego Mszaneckiego ${ }^{14}$.

${ }^{10}$ J. Flaga, Bractwa i sodalicje jezuickie w Polsce w 2 pot. XVIII w., ,Summarium”, 1974, nr 3(23), s. 146; Tegoż, Z problematyki jezuickich bractw i sodalicji w XVIII wieku, w: Państwo-Kościót-Niepodległość, red. J. Skarbek, J. Ziółek, Lublin 1986, s. 175.

${ }^{11}$ B. Kumor, Kościelne stowarzyszenia świeckich na ziemiach polskich $w$ okresie przedrozbiorowym, „Prawo Kanoniczne”, 10 (1967) nr 1-2, s. 339.

${ }^{12}$ LNNB, f. 3, sp. 663/1-Przywilej Mikołaja Potockiego dla monasteru bazyliańskiego w Buczaczu, k. 7-11v; F. Zych, Dwie uroczystości szkolne w nowym budynku gimnazjalnym, w: I Sprawozdanie Dyrekcji c.k. Gimnazyum w Buczaczu za rok szkolny 1900, Stanisławów 1900, s. 3-4; Pamiątki buczackie, wyd. S. Barącz, Lwów 1882, s. 112, 120, 128.

${ }^{13}$ LNNB, f. 3, sp. 642-Księga zapisów Sodalicji Mariańskiej w bazyliańskim gimnazjum w Buczaczu 1758-1836; f. 3, sp. 640-Księga rozchodów Kongregacji większey szkół buczackich pod dozorem WW. OO. Bazylianów Prow. Litew. sporządzona Roku 1774. Z drugiej strony Księgi wpisywano przychody.

${ }^{14}$ LNNB, f. 5 (Ossolińskich), sp. 6196/II-Diarium actorum Collegij Buczacensi connotatorum per Patrem Hieronymum Nereziusz 1750; f. 5, sp. 4787/II-Acta quibus Publica Scholarum Buczacensium inscribuntur Opera.... 1758-1763; f. 5, sp. 4788/II-Acta continentia in se opera ... 17631767; f. 5, sp. 4789/II-Acta, quibus publica scholarum...1769-1774; f. 5, sp. 4790/II-Acta, quibus publica scholarum Buczacensium, inscribuntur opera...1774-1781; Centralne Państwowe Archiwum Historyczne Ukrainy we Lwowie (dal. cyt. CPAH), f. 684 (Protoihumenat monasterów Zakonu Św. Bazylego Wielkiego prowincji Zbawiciela we Lwowie), op. 1, sp. 1103-Inwentarz majątku ruchomego i nieruchomego oraz biblioteki monasteru w Buczaczu 1769. 
Przywilej na założenie Sodalicji Mariańskiej w kolegium bazyliańskim w Buczaczu nadał 4 III 1758 r. papież Benedykt XIV. Wymieniano w nim ołtarz konfraterni, czyli sodalicji uczniów pw. Zwiastowania NMP. Przywilej został zatwierdzony przez unickiego biskupa lwowskiego Leona Szeptyckiego 12 V 1758 r. $^{15}$ Z opisu kaplicy bazyliańskiej z 1769 r., która funkcjonowała przed poświęceniem budowanej nowej cerkwi, wnosić można, że sodalicja dysponowała ołtarzem bocznym pozostającym pw. Najświętszej Maryi Panny Niepokalanie Poczętej. Spośród sprzętów znajdujących się w kaplicy do towarzystwa należały jeszcze katedra kongregacyjska oraz obrazy malowane na płótnie i blasze miedzianej ${ }^{16}$.

Wprowadzenie sodalicji odbyło się w święto Opieki NMP w 1758 r., w obecności ówczesnego rektora o. Piotra Łapinkiewicza oraz profesora retoryki i prefekta kolegium o. Porfirego Skarbka Ważyńskiego ${ }^{17} .19$ XI 1758 r. odbyła się promulgacja, czyli uroczyste ogłoszenie nazwiska studenta, który został wybrany pierwszym prefektem kongregacji. W tym akcie uczestniczyło wielu zaproszonych gości. Prefektem został Antoni Stawski, syn cześnika zakroczymskiego, uczeń syntaksy. $Z$ racji powierzenia synowi zaszczytnej funkcji cześnik podejmował studentów obiadem w klasztorze. Spotkaniu towarzyszyła muzyka w wykonaniu kapeli pałacowej Mikołaja Potockiego oraz trębaczy - uczniów kolegium ${ }^{18}$. Promulgacja odbywała się $\mathrm{w}$ sali oddanej na potrzeby kongregacji, odpowiednio udekorowanej i wyposażonej. Oprócz ołtarza stawiano w niej tron, na którym zasiadał nowo obrany prefekt ${ }^{19}$.

Pod datą 13 XII 1758 r. w albumie kongregacji zapisano skład władz Sodalicji Mariańskiej pw. Zwiastowania NMP w gimnazjum bazyliańskim w Buczaczu. W kongregacji występowały dwie grupy członków: sodalisi oraz nowicjusze (tyronowie). Jak odnotował ks. Jędrzej Kitowicz: „Sodalis był ten, który był przyjęty do księgi sodaliskiej i w obecności kongregacyi uczynił niby profesyją; był to pewny formularz, którym sodalis każdy obowiązywał się szczególniejszym sposobem służyć Najświętszej Pannie tak nabożeństwem do niej, jako też niewinnym życiem. Tyro nazywał się, który dopiero do kongregacyi przystępował i miał pewne czasy do wysługi i nauczenia się sodalitatis obowiązków zamierzone. Sodalisowie na kongregacyjach zasiadali w ławkach, tyronowie stali na środku w oratoriach albo klęczeli, jeżeli co przewinili; i była to wielka kara na sodalisa, kiedy z ławki został rugowanym i w rząd między tyronów stojących, tym bardziej klęczących, skazanym" ${ }^{20}$.

${ }^{15}$ LNNB, f. 3, sp. 308-Kronika monasteru w Podhorcach 1763, k. 142-142v. Karta z informacją o sodalicji w Buczaczu została najpewniej pomyłkowo dołączona do kroniki monasteru w Podhorcach.

${ }^{16}$ CPAH, f. 684 , op. 1 , sp. 1103 , k. 1.

${ }^{17} \mathrm{LNNB}$, f. 3, sp. 642, k. 2v-3. Wpisy prowadzone były z przerwami do $1836 \mathrm{r}$.

${ }^{18}$ LNNB, f. 5, sp. 6196/II, k. 22; sp. 4787/II, s. 6. Pod koniec listopada i w grudniu 1758 r. rektorem kolegium był o. Maurycy Kaskowicz.

${ }^{19}$ LNNB, f. 5, sp. 6196/II, k. 44.

${ }^{20}$ J. Kitowicz, Opis obyczajów za panowania Augusta III, opr. R. Pollak, t. I, Wrocław 2003, s. 23. 
Nadzór nad sodalicją z ramienia zakonników sprawował prefekt kolegium, pełniący najczęściej również obowiązki profesora retoryki. Wśród urzędników tworzących władze kongregacji w Buczaczu występowali zarówno prefekt organizacji, jak i prefekt nowicjuszy (tyronów). Najwyższa władza w kongregacji należała do prefekta, któremu pomagali: zastępca tytułowany wiceprefektem, sześciu asystentów oraz sześciu ich zastępców. Ponadto wybierano sekretarza i jego zastępcę, skarbnika i dwóch zastępców, czterech konsultorów, dwóch lektorów, oratora maryjnego, dwóch marszałków, kancelistę, czterech chorążych, czterech doradców, dwóch kantorów, dwóch cenzorów, dwóch zakrystianów, dwóch odźwiernych (stróżów) oraz dwóch odwiedzających chorych. Z kolei pomocą prefektowi nowicjuszy służyło dwóch instruktorów, których zadaniem była opieka nad kandydatami na sodalisów. Liczba sodalisów pełniących funkcje była zatem znaczna, mimo że niektórym osobom powierzano kilka urzędów, np. Adam Nowakowski pełnił obowiązki asystenta, sekretarza, oratora maryjnego oraz prefekta nowicjuszy ${ }^{21}$. Ta hierarchia urzędów sodaliskich była bardzo rozbudowana $\mathrm{w}$ porównaniu $\mathrm{z}$ wytycznymi zawartymi $\mathrm{w}$ statutach kongregacji, wydawanych w okresie XVI-XVIII w. Wymieniano w nich bowiem prefekta, dwóch asystentów, sekretarza oraz konsultorów, których mogło być dwunastu w przypadku licznej kongregacji lub sześciu, gdy sodalisów było niewielu. Ponadto statut dopuszczał wybór nadzorcy świątyni, zakrystiana i odźwiernego ${ }^{22}$. Zatem uznać należy, iż dostosowano organizację sodalicji do warunków i potrzeb miejscowego środowiska.

Do sodalicji dopuszczano również konwiktorów, a więc uczniów korzystających z utrzymania w klasztorze. W grudniu $1760 \mathrm{r}$. w promulgacji uczestniczyło ich aż trzech ${ }^{23}$. 5 IV 1769 r. po raz pierwszy przyjęto do kongregacji dziewczęta. Były to trzy córki szlachty urzędniczej pełniącej funkcje ekonomów i zarządców dóbr Potockiego. Przyjmowanie do sodalicji dziewcząt było możliwe dzięki zgodzie papieskiej z $1751 \mathrm{r}$. Z powodu nieznajomości łaciny ich przyjęcie wymagało wystarania się o tekst formuły i instrukcji dotyczących obowiązków sodaliskich sporządzony w języku polskim. Jak odnotowano w źródłach odpowiednie formularze prefekt kolegium buczackiego sprowadził z drukarni we Lwowie ${ }^{24}$.

Podczas posiedzenia kongregacji 17 XII 1758 r., w niedzielne popołudnie, uchwalono procedurę przyjęcia do bractwa oraz warunki złożenia przysięgi. Wstępujący miał obowiązek wpłacić albo pieniądze według określonej ilości, albo oddać wosk na świece do oświetlenia i upiększenia ołtarza kongregacji. Po wpisaniu do kongregacji sodalis otrzymywał pismo potwierdzające przynależność do bractwa podpisane przez prefekta i sekretarza z pieczęcią sodalicji. W zależności od rozmiaru i formy pisma wpłacał za nie trzy lub dwa tynfy. W maju $1759 \mathrm{r}$.

${ }^{21}$ LNNB, f. 3, sp. 642, k. 2v-3.

${ }^{22}$ Leges et statute Congregationum Beatissimae Virginis Mariae quae in Collegiis Societatis Jesu institutae, atque a Sede Apostolica approbatae varijs Indulgentijs et gratijs exornatae sunt, Polociae 1794, s. 4-5, 57.

${ }^{23}$ LNNB, f. 5, sp. 6196/II, k. 44.

${ }^{24}$ Tamże, k. 156. 
podczas zebrania kongregacji ustalono jednogłośnie, ażeby w jedną środę każdego miesiąca odprawiać mszę św. za zmarłych sodalisów ${ }^{25}$.

Rok później, 11 XI 1759 r. ogłoszono prefektem kongregacji Stefana Gawrońskiego, syna stolnika łomżyńskiego, siostrzeńca proboszcza kościoła farnego w Buczaczu. Z tej racji poczęstunek dla studentów i władz szkolnych przygotował proboszcz buczacki na plebaniii ${ }^{26}$. Mowę gratulacyjną wygłosił Józef Bachrynowski ${ }^{27}$. Od 1760 r. wybory prefekta odbywały się dwa razy w roku: w maju i listopadzie, zaś po nich następowała uroczysta promulgacja urządzana najczęściej w święto maryjne w maju i grudniu ${ }^{28}$. Urząd ten w latach sześćdziesiątych XVIII w. pełnili przedstawiciele szlachty, wyróżniający się zdolnościami, osiąganymi wynikami w nauce oraz popularnością wśród pozostałych sodalisów.

Wśród przedmiotów służących działalności sodalicji w Buczaczu wymieniano ołtarzyk drewniany posrebrzany i pozłacany z obrazem malowanym na płótnie przedstawiającym Matkę Bożą Niepokalanie Poczętą, krucyfiks, drewnianą ambonę, krzesła z poręczami i tapicerką skórzaną, lichtarze cynowe i mosiężne, wota srebrne, obrazy na płótnie i blasze, chorągwie, antepedium zielone, sukno niebieskie do nakrywania ołtarza, tuwalnie i firanki, skrzynkę do przechowywania pieniędzy towarzystwa, formy do pieczenia opłatków i wykrawania komunikantów, pieczęć kongregacyjną oraz „Żywoty świętych” Piotra Skargi ${ }^{29}$.

Ważnym aspektem działalności kongregacji było uroczyste obchodzenie świąt maryjnych. 7 XII 1759 r. w wigilię Niepokalanego Poczęcia NMP (19 XII według kalendarza gregoriańskiego) miała miejsce procesja sodalisów, podczas której użyto dwóch nowo sprawionych chorągwi. Następnie w cerkwi odbyła się recytacja ku czci Matki Bożej, którą wygłosił podczaszyc wendeński Józef Gawroński, uczeń poetyki. Równie uroczyście obchodzono dzień świąteczny -8 grudnia. Wówczas sodalisi wzięli udział w nieszporach łacińskich, po których odbyła się procesja z chorągwiami wokół klasztoru. Później w cerkwi uczeń retoryki Tomasz Węgierski wygłosił orację ku czci Niepokalanej. Następnie odprawiono nieszpory w języku ruskim, a następnie sodalisi przeszli wraz z obrazem do siedziby kongregacji, gdzie odmówiono litanię loretańską. Dla uczczenia święta ganek w budynku szkoły oświetlono lampami, które paliły się długo w nocy ${ }^{30}$.

25 III 1760 r. w święto Zwiastowania NMP sodalisi już od rana czcili swoją patronkę. Do siedziby kongregacji przyniesiono obraz Matki Bożej oraz odprawiono śpiewaną mszę św., zaś po południu odbyły się nieszpory łacińskie i procesjonalnie udano się do cerkwi, gdzie wysłuchano oracji poświęconych Najświętszej Marii Pannie. Wygłosili je Adam Nowakowski, uczeń retoryki Kazimierz Krajeński, uczeń z klasy poetyki Roch Gawroński cześnikowic wendeński oraz Jan Sławiński i Ignacy Gawroński. Po nich udano się do kongregacji, gdzie pre-

${ }^{25}$ LNNB, f. 3, sp. 665/3-postanowienia Sodalicji Mariańskiej w Buczaczu przyjęte w 1758 r. i potwierdzone w $1759 \mathrm{r}$. w sprawie prawa przyjęcia do towarzystwa i procedury złożenia przysięgi, k. 1.

${ }^{26}$ LNNB, f. 5, sp. 6196/II, k. 30.

${ }^{27}$ LNNB, f. 5, sp. 4787/II, s. 139-143.

${ }^{28}$ Tamże, s. 279-281, 452-456, 551; f. 5, sp. 6196/II, k. 43, 44, 47v.

${ }^{29} \mathrm{CPAH}$, f. 684 , op. 1 , sp. 1103, k. 5.

${ }^{30}$ LNNB, f. 5, sp. 6196/II, k. 30v. 
fekt szkoły o. Porfiry Skarbek Ważyński odprawił akatyst, a następnie odmówiono litanię po łacinie oraz „Pod Twoją obronę” po rusku ${ }^{31}$.

Od 7 XII 1767 r. urządzali sodalisi procesję w wigilię Niepokalanego Poczęcia NMP do kościoła farnego w Buczaczu. Wyruszali po odprawieniu nieszporów, w zorganizowanym pochodzie, w którym na specjalnie udekorowanych i oświetlonych lampami noszach niesiono obraz kongregatycki, przedstawiający Matkę Bożą Niepokalanie Poczętą. Na tym postumencie siedziało dwóch najmłodszych studentów, podtrzymujących obraz jako aniołowie. Nosze niosło czterech studentów przebranych w stroje symbolizujące cztery strony świata. Była również grupa uczniów ubrana po husarsku, strzelająca na wiwat ze strzelb. Jak zapisał kronikarz: „spektatorów było wiele, bo to się w niedzielę działo”. Po przyjściu do kościoła farnego prefekt szkół miał kazanie do zgromadzonych, zaś nabożeństwo zakończyłoodmówienielitaniiloretańskiej. Obrazkongregacjipozostawionowkościele farnym do dnia następnego. 8 XII w kaplicy klasztornej już o 4 rano odprawiono jutrznię, a po niej było kazanie dla studentów wygłoszone przez wicerektora Ihnatowicza. Następnie po południu w kościele farnym odprawiono mszę św. oraz nieszpory w języku ruskim, po czym około godz. 18 procesjonalnie odprowadzono obraz z powrotem do kaplicy bazyliańskiej. Tu profesor syntaksy Aleksander Żórawski wygłosił egzortę dla młodzieży szkolnej, zaś nabożeństwo zakończyła litania do Pana Jezusa ${ }^{32}$. Na tę procesję studenci pożyczyli stroje od kapeli farskiej ${ }^{33}$. Podobnie obchodzono święto Niepokalanego Poczęcia NMP w następnym roku. Wtedy również studenci zanieśli w uroczystej procesji obraz do kościoła farnego, gdzie przez całą noc trwało nabożeństwo. Drugiego dnia po powrocie do siedziby sodalicji uczniowie retoryki prezentowali przygotowane oracje ku czci Niepokalanej. Z racji stacjonowania wówczas w Buczaczu oddziału Kozaków prefekt kolegium musiał uzyskać zgodę komendanta na zorganizowanie procesji $\mathrm{i}^{34}$.

Przynależność do Sodalicji Mariańskiej uprawniała do uroczystego pogrzebu w przypadku śmierci sodalisa. Tak też stało się w styczniu 1770 r., kiedy umarł student Dymitr Jaremowicz. W jego pogrzebie uczestniczyli członkowie kongregacji, odprowadzając go ze świecami do grobu. Podobnie sodalicja żegnała ogrodnika Michała Smereckiego, zatrudnianego przez Mikołaja Potockiego, który ofiarował na rzecz kongregacji $24 \mathrm{złp}^{35}$.

Sodalicja Mariańska w Buczaczu prowadziła księgę dochodów i wydatków kongregacji rozpoczętą w 1774 r. Ostatnie wpisy odnotowane w niej dotyczyły 1880 r. Wydatkowano głównie środki na uświetnienie nabożeństw odprawianych w święta maryjne, zwłaszcza Niepokalane Poczęcie NMP ${ }^{36}$. W 1762 r. świece

\footnotetext{
${ }^{31}$ Tamże, k. 36.

${ }^{32}$ Tamże, k. 142.

${ }^{33}$ Tamże, k. 142v.

${ }^{34}$ Tamże, k. 153-153v.

${ }^{35}$ Tamże, k. 160.

${ }^{36}$ LNNB, f. 3, sp. 640. Z drugiej strony księgi wpisywano przychody.
} 
potrzebne w trakcie ceremonii i nabożeństw wicerektor kolegium kupował aż w Stanisławowi ${ }^{37}$.

Sodalicja Mariańska funkcjonowała również w kolegium prowadzonym przy monasterze bazyliańskim w Hoszczy, w województwie wołyńskim. Sam klasztor przy cerkwi św. Michała ufundowała kasztelanowa smoleńska księżna Regina z Hoyskich Sołomerecka najprawdopodobniej na początku 1639 r., z zadaniem, „aby szkoły publiczne byli i młódź wszelkiej kondycji ludzi, swoją należytą edukacyją miała i oraz aby tejże młodzi zakonnicy mnisi edukacyją pomienioną dawali”38. Szkoła bazyliańska miała przeciwstawić się słynnej placówce ariańskiej funkcjonującej w Hoszczy i spowodować powrót wiernych do Cerkwi ${ }^{39}$. Pod koniec XVII w. klasztor hoszczański przeszedł pod zwierzchnictwo prawosławnego biskupa lwowskiego Józefa Szumlańskiego, który przyjął unię z Kościołem łacińskim, a w związku z tym i klasztor stał się unickim. W I połowie XVIII w. przy monasterze funkcjonowała szkoła dla młodzieży świeckiej ${ }^{40}$.

W 1755 r. w aktach wizytacji kolegium hoszczańskiego wspominano o funkcjonowaniu Sodalicji Mariańskiej skupiającej studentów retoryki. Posiadali oni ołtarzyk oraz akcesoria używane do nabożeństw. Ołtarz usytuowany był w dużym refektarzu znajdującym się na piętrze kolegium. Nie odnotowano szczegółów dotyczących wyglądu tegoż ołtarzyka oprócz tego, że wykonany był stolarska robotą oraz posiadał mensę, zaopatrzoną w szuflady. Wśród akcesoriów używanych przez sodalisów znajdowały się m.in. antepedium, jedna para lichtarzy cynowych gdańskich, druga para lichtarzy cynowych stołowych, obrazy i bielizna ołtarzowa, laski marszałkowskie służące do procesji ${ }^{41}$. Szkoła w Hoszczy została w $1777 \mathrm{r}$. przeniesiona do Ostroga, gdzie bazylianie przejęli kolegium pojezuickie ${ }^{42}$. W nowych warunkach również kontynuowana była działalność kongregacji, co nie spotkało się z pozytywną oceną wizytatorów Komisji Edukacji Narodowej. W 1782 r. ks. Szczepan Hołowczyc zabronił członkom organizacji wydawania „uczt podczas elekcji prefektów sodalistwa" ${ }^{43}$.

W 1784 r. odnowiono działalność Sodalicji Mariańskiej w kolegium w Owruczu, przejętym przez bazylianów po kasacie zakonu jezuitów. W 1783 r. Komisja Edukacji Narodowej przekazała bazylianom prowadzenie tej placówki przemia-

${ }^{37}$ LNNB, f. 5, sp. 6196/II, k. 82v.

${ }^{38}$ Państwowe Archiwum Obwodu Tarnopolskiego (dal. cyt. PAOT), f. 258, op. 3, sp. 1254-Wizyty różnych klasztorów kordonu polskiego podług alfabetu w katalogu zebrane i oprawione 1776 Anno, k. 62v; T. Kempa, Sołomerecka z Hoyskich Regina, w: Polski Stownik Biograficzny, t. XL, Warszawa-Kraków 2000-2001, s. 325-326.

${ }^{39}$ J. M. Giżycki, Z przeszłości Hoszczy na Wołyniu, Kraków b.r.w., s. 55-56. Akt fundacji potwierdzono w 1639 i $1640 \mathrm{r}$.

${ }^{40}$ Tamże, s. 60-63.

${ }^{41}$ PAOT, f. 258, op. 3, sp. 1254, k. 43v, 58-58v, 66v.

${ }^{42}$ LNNB, f.3, sp. 816/4-Kronika monasteru ostrogskiego, k.1-2.

${ }^{43}$ Miterzanka, Działalność pedagogiczna, s. 175; W. Wisłocki, Ks. Szczepana Hołowczyca Raport Wizyty Generalnej poludniowo-wschodnich wydziałów szkolnych odprawionej imieniem Komisyi edukacyjnej w roku 1782, „Archiwum do Dziejów Literatury i Oświaty w Polsce”, seria I, t. 1, 1878, s. 37. 
nowanej na 3-klasową szkołę podwydziałową. Ogłoszenie wznowienia działalności kongregacji i pierwsza elekcja władz nastąpiła w 1784 r. pod przewodnictwem profesora wymowy o. Jozafata Przywidzkiego. Profesorowie wymowy i literatury byli opiekunami tamtejszej sodalicji jako prezesi. Kongregacja za szczególnych patronów, oprócz Najświętszej Marii Panny Niepokalanie Poczętej, przybrała sobie śś. Bazylego Wielkiego, Jana Chryzostoma Damasceńskiego, Kazimierza, Jozafata oraz Stanisława Kostkę ${ }^{44}$.

Co roku w grudniu odbywały się kolejne elekcje władz sodalicji, złożonej z kongregacji większej (maioris) i mniejszej (minoris). Podział na dwie lub trzy grupy zależał od liczby uczniów w kolegium. Tam, gdzie prowadzono kurs filozofii sodalicja dzieliła się na trzy grupy: większa (maior, maxima), średnia (media) oraz mniejsza (minor). W kolegiach bazyliańskich najczęściej najwyższą klasą była retoryka. Liczba uczniów z reguły również była mniejsza niż w kolegiach jezuickich, stąd rzadko wyróżniano grupy. W Owruczu młodzież starsza z klas poetyki i retoryki tworzyła kongregację większą, zaś uczniowie klas gramatyki i syntaksy należeli do kongregacji mniejszej ${ }^{45}$. Na ogłoszenie składu władz sodaliskach zapraszano gości, najczęściej dobrodziejów klasztoru i kolegium oraz rodziny uczniów. Wybierano prefekta, wiceprefekta, sekretarza oraz asystentów (po dwóch) dla kongregacji większej i mniejszej. Ponadto wśród urzędników kongregacjalnych byli: marszałkowie, chorążowie, lektorzy (deklamatorzy), instruktorzy nowicjuszy, prefekt i wiceprefekt kaplicy, pomocnicy, stróże (odźwierni), cenzorzy (postrzegacze dobrego porzadku), odwiedzający chorych. Ich liczba oraz nazwa piastowanej funkcji zmieniały się na przestrzeni lat. Funkcje prefektów i wiceprefektów pełnili synowie szlachty urzędniczej, np. w 1785 r. prefektem kongregacji większej był Alojzy Dubrawski podczaszyc żydaczowski ${ }^{46}$. Rezultaty przeprowadzonych wyborów zapisywano w księdze sodalicji. W 1787 r. zapisano wymogi stawiane osobom pełniącym godności w kongregacji: „Wszystkie ludzkiej społeczności Towarzystwa dla ubezpieczenia wiecznie trwałości za najpierwszą być sądzę powinnością: z pomiędzy zgromadzenia swego roztropnego i cnotliwego męża na najwyższy stopień zwierzchności obierać, wynosić, ogłaszać i mu być podległym; którenby niemi zarządzał, ich życia i majątków bronił i ze wszelka czułością do ich zewnętrznego i wewnętrznego uszczęśliwienia przyczyniał się. Jakoż te przedsięwzięcia narodów, że są uskutecznione, każdy przyzna, gdy wszystkie Towarzystwa myślą i doświadczeniem zwiedzi i przypatrzy się, że żadna społeczność bez zwierzchności nie znajduje się. Ten przeto na wymaganiu samej natury gruntujący się porządek i nasze zachowując Towarzystwo Niepokalanego Poczęcia Najświętszej Maryi Panny według zwyczaju corocznie obierając

${ }^{44}$ Biblioteka Czartoryskich w Krakowie (dal. cyt. BCz), rkps 1943-Księga dziejów sodaliskach Zgromadzenia owruckiego pod dozorem Ichmc. XX. Bazylianów zostającego sporządzona w $\mathrm{r}$. 1786 w Owruczu, s. 5-6, 59. O Sodalicji w kolegium w Owruczu pisał J. M. Giżycki (Wołyniak), Bazylianie w Owruczu, „Przewodnik Naukowy i Literacki”, 39 (1911) s. 151-156.

${ }^{45}$ BCz, rkps 1943, s. 6; M. Inglot, Kongregacje (Sodalicje) Mariańskie w szkołach jezuickich, s. 277; Flaga, Z problematyki jezuickich bractw, s. 171. Podział na dwie grupy odnotował Jędrzej Kitowicz, Opis obyczajów, s. 21.

${ }^{46} \mathrm{BCz}$, rkps 1943, s. 6-7. 
na urząd przełożeństwa i biegącego Roku ku pomnożeniu nieustannej czci Monarchini Nieba i Ziemi za rządcę dla siebie obrało syna walecznych przodków Familią w obywatelstwie zaszczyconego, a między młodzieżą szkolną wielkiemi duszy przymiotami kwitnącego, któren w przytomności łaskawie nam darujących swą bytność WW. Gości Prefektem Kongregacji naszej ogłasza się W. Imć Pan Dominik Szyszko cześnikowic smoleński. Aże pominąwszy dziecinne lata, które wsparcia potrzebują, wiadomo jest każdemu, iż najwyższe wszelkie urzędy do pomocy swojej innych podręcznych urzędników przybierają, którzy by zwierzchność społeczeństwa, radą i współrządzeniem wspierali. Dlatego, którzy jednomyślną uchwałą, na jakie urzędy do wspierania tej zwierzchności są wyniesieni chciejcie cierpliwie i łaskawie posłuchać. Współrządcą, czyli wiceprefektem starszego zgromadzenia jest obrany cnotą i zaszczytem imienia w Ojczyźnie znakomity JP. Seweryn Potocki, sekretarzem zaś Józef Sobolewski. Urząd asystenta pierwszego zlecony jest Janowi Ochockiemu cześnikowicowi mozyrskiemu, za drugiego asystenta ogłasza się JM. Pan Wyhowski Celestyn podczaszyc czernichowski. Jako zaś pieczołowite jest Towarzystwo nasze o utrzymanie należytego między sodalisami porządku, już mając baczność na ich postępki, już ich do cnotliwego, przykładnego i chrześcijańskiego życia prowadząc, tak troskliwe będąc w pomnażaniu chwały N. Maryi Panny przez przysposobienie coraz więcej Jej czcicielów, stara się, aby i między sposobiącemi się do tego Towarzystwa był jakowyś zachowany porządek, któren koniecznie zwierzchności wymaga. Przeto tego mniejszego zgromadzenia jednomyślnie obrało za rządcę, czyli prefektem Minores Congregationis cnotliwego i przykładnego młodzieniaszka Wincentego Paszkiewicza skarbnikowica parnawskiego, za współrządcę, czyli wiceprefektem jest obrany Antoni Stocki, asystentem pierwszym Trzeciak Andrzej, asystentem drugim Ludwik Żmiejewski”"47.

Tabela 1. Przyjęcia do Sodalicji Mariańskiej w kolegium bazyliańskim w Owruczu w latach 1785-1792

\begin{tabular}{|c|c|c|}
\hline Rok & Chlopcy & Dziewczęta \\
\hline 1785 & 1 & 7 \\
\hline 1786 & 35 & 12 \\
\hline 1787 & 4 & - \\
\hline 1788 & 1 & - \\
\hline 1789 & 12 & - \\
\hline 1790 & 5 & - \\
\hline 1791 & 10 & - \\
\hline 1792 & 2 & - \\
\hline
\end{tabular}

Źródło: BCz, rkps 1943, s.7-49.

Przyjęcie do sodalicji w przedstawionym wyżej przedziale czasowym cechuje znaczne zróżnicowanie liczby osób, wahające się między 1 a 47. Początkowo po

${ }^{47} \mathrm{BCz}$, rkps 1943, s. 10-11. 
wznowieniu działalności kongregacji wpisywano do niej również dziewczęta. Odnotowano ich obecność w 1785 i 1786 r. Domniemywać można, że były to przedstawicielki rodzin szlacheckich osiadłych w pobliżu szkoły lub związanych z działalnością gospodarczą monasteru. Nazwiska dziewcząt wskazywały na to, że były one związane z kolegium poprzez braci, którzy tutaj pobierali naukę.

Podczas zebrań sodalicji zbierano dobrowolne składki do wspólnej kasy, np.

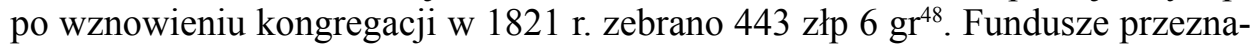
czane były na zakup książek, z których korzystali sodalisi. W latach 1786-1789 zakupiono 10 tomów, wśród których znalazły się prace Tomasza a Kempis („O naśladowaniu Chrystusa”), ks. Franciszka Nonnota („Dykcjonarz filozoficzny religii, w którym gruntują się wszystkie wiary św. artykuły lżone od niewiernych i odpowiada się na wszystkie ich zarzuty”), ks. Remigiusza Ładowskiego („Historia naturalna Królestwa Polskiego"), mowy starożytnych i współczesnych retorów. Ponadto na potrzeby kongregacji sprowadzono drukowane artykuły sodalicji zarówno w języku polskim, jak i łacińskim, a także formularze dla nowych członków kongregacji ${ }^{49}$.

Sodalicja prowadziła również księgę, do których zapisywano mowy wygłaszane przy okazji rozpoczęcia nauki i wyborów do władz towarzystwa, dzieje kongregacji oraz rejestr dochodów i wydatków ${ }^{50}$. Wśród odnotowanych oracji większość miała charakter gratulacji związanych z objęciem urzędu prefekta kongregacji, w których podkreślano przymioty elekta. Zanotowano również podziękowania prefektów za dokonany wybór i zaufanie. Tradycyjnie orator wyrażał przy tym życzenie: „Charakterem duszy naszej niestartym będzie wywdzięczać się za to, a czyny nasze trudy i prace około uszczęśliwienia Ojczyzny podejmowane, biorąc za wzór do naśladowania uwieczniać i podawać pamięci w wiekopomne czasy, myślą i obowiązkiem jest naszym. Tobie zaś przezacna młodzi szkolna za odebrane łaskawe względności słusznie zapisuję na swoim sercu wdzięczność i życzę, abyś będąc teraz w wykonywaniu obowiązków pilną, w pobożności przykładną $\mathrm{i}$ w inne przymioty duszy obfitą, Ojczyzny która $\mathrm{z}$ ciebie chce mieć życzliwych synów, światłych obywatelów, i gorliwych o dobro Jej patriotów była nadal użyteczną". Mowy wygłaszane były najczęściej w języku polskim lub łacińskim, ale również wprowadzano teksty w obcych językach nowożytnych, np. francuskim i niemieckim. Niejednokrotnie miały formę wierszowaną. Niekiedy dotyczyły aktualnych spraw i związane były z obchodzonymi uroczystościami. Tak było w przypadku oracji wygłoszonej 8 V 1791 r. przez ucznia klasy III Mariana Ochockiego z okazji uroczystości św. Stanisława patrona Korony Polskiej. Święto to stało się okazją do ukazania zasług króla Stanisława Augusta Poniatowskiego dla ratowania kraju i reformowania ustroju państwa, czego efektem było uchwalenie konstytucji 3 V $1791 \mathrm{r}^{51}$

\footnotetext{
${ }^{48} \mathrm{BCz}$, rkps 1943, s. 70.

${ }^{49}$ Tamże, s. 61.

${ }^{50}$ Tamże. W źródle pisano o trzech księgach, ale wpisy dotyczące wymienionych spraw zostały zszyte w jednym tomie.

${ }^{51}$ Tamże, s. 20-49.
} 
Oprócz ksiąg kongregacja gromadziła przedmioty służące uświetnieniu nabożeństw i procesji oraz stanowiące oznaki władzy urzędników brackich. Wśród nich były choraggwie oraz obrazy brackie noszone podczas procesji, z wyobrażeniem Matki Bożej oraz św. Kazimierza. Godność marszałków sodalicji podkreślały drewniane laski czarno malowane oprawione w posrebrzaną blachę. Kongregacja zapewniała też świece oraz lampy, które przechowywano w specjalnej szafie z zamykanymi szufladami. Ponadto do przystrojenia brackiego ołtarza służyły obrusy i lichtarze. Sodalicja posiadała też pieczęć żelazną do odciskania formuł kongregacji wręczanych jej członkom ${ }^{52}$.

Zapisy w księdze sodalicji w Owruczu sięgały do 1791 r. Ponowne odnowienie kongregacji nastąpiło w grudniu 1821 r., dzięki ówczesnemu opatowi owruckiemu o. Pachomiuszowi Lewickiemu doktorowi teologii i kawalerowi orderu św. Anny ${ }^{53}$. Po wznowieniu działalności doszło w sodalicji do nieporozumień i sporów związanych z podważaniem autorytetu urzędników kongregacji. $10 \mathrm{X}$ 1822 r. prefekt Jan Zahorowski wydał odezwę do sodalisów, w której przypomniał konieczność przestrzegania praw towarzystwa. Powołał się na punkty dziewiąty (,wystrzegać się popełniać występków gorszących, pokora i skromność ma ich serce i duszę zdobić. Obopólna zgoda i uległość zwierzchności tak kongregatyckiej jako i szkolnej ma być ich zaletą”) i dziesiąty („Prezesowi, Prefektowi i innym urzędnikom podług stopnia posłuszeństwo i uszanowanie okazywać będą"). Niestety w księdze sodalicji nie zapisano całości regulaminu ${ }^{54}$. Sprawa konfliktu miedzy sodalisami zdominowała zebranie kongregacji 17 XII 1822 r. W jego trakcie prezes towarzystwa, profesor wymowy i literatury Juwenalis Proniewicz ,za powszechną zgodą swoich współkolegów i wolą rektora" wskazał studentów na stanowiska prefekta, wiceprefekta i sekretarza. Obiór innych urzędników odłożono na czas późniejszy. Ponadto zniesiono sądy sodalicji, zaś w razie konieczności ukarania występnych decyzję o karze miał podjąć prezes w porozumieniu z rektorem. Zapowiedziano również ogłoszenie tych decyzji podczas spotkania 2 II 1823 r. Był to już ostatni wpis dotyczący dziejów kongregacji w Owruczu ${ }^{55}$.

O funkcjonowaniu Sodalicji Mariańskiej w szkole bazyliańskiej w Podubisiu na Żmudzi pochodziły wzmianki z początku XIX w. W 1801 r. odnowiono tamtejszą kongregację pw. Niepokalanego Poczęcia NMP. Notatka w księdze sodalicji pozwalała na wniosek, iż towarzystwo skupiające tamtejszych uczniów funkcjonowało już $\mathrm{w}$ drugiej połowie XVIII w. ${ }^{56}$ Monaster bazyliański został ufundowany w tym miasteczku na mocy fundacji Jana i Antoniego Beynerów

${ }^{52}$ Tamże, s. 67.

${ }^{53}$ Tamże, s. 49.

${ }^{54}$ Tamże, s. 58-59.

${ }^{55}$ Tamże, s. 60. Według J. M. Giżyckiego (Wołyniaka), Bazylianie w Owruczu, s. 372, 446 informacje dotyczące działalności sodalicji kończyły się na $1821 \mathrm{r}$.

${ }^{56}$ BCz, rkps 1943, s.110. Zapisy dotyczące Sodalicji Mariańskiej działającej w szkole podubiskiej znajdują się w drugiej części rękopisu zawierającego dzieje kongregacji w Owruczu. „Szkoły Podubiskie pod dozorem XX. Bazylianów zostające pragnąc najgorliwiej służyć i pomnażać chwałę najdostojniejszej Maryi Panny ustanowiły, aby Bractwo Niepokalanego Jej Poczęcia od dawnych czasów na tem miescu utrzymywane nie było i teraz zaniedbane". 
z października 1748 r. W 1777 r. wskutek pobożnych legacji klasztor posiadał trzy majątki ziemskie: Podubiś, Mekie oraz Pobiałyszki. W 1773 r. bazylianie utworzyli szkołę określaną jako parafialną, ale w źródłach wspominano o nauczaniu w niej retoryki oraz istnieniu klasy gramatyki i syntaksy. W 1790 r. szkołę zreorganizowano jako powiatową o czterech klasach według przepisów Komisji Edukacji Narodowej. Nauczano w niej łaciny, arytmetyki, religii, historii i geografii, retoryki, fizyki, etyki oraz języków rosyjskiego i francuskiego. Liczba uczniów na początku XIX w. wahała się w przedziale 150-300 osób. Przeważały dzieci szlacheckie, ale również w szkole podubiskiej kształcono młodzież wywodzącą się z chłopstwa i mieszczaństwa. Od 1825 r. zwiększono liczbę lat nauki w dwóch klasach, placówka była wówczas praktycznie 6-letnim gimnazjum. W 1832 nastąpiła laicyzacja szkoły, gdy zarząd nad nią odebrano bazylianom. Kres jej istnienia nastąpił w 1835 r., zaś w roku następnym zlikwidowano monaster, oddając go duchowieństwu prawosławnemu ${ }^{57}$.

Zachowane informacje dotyczące Sodalicji Mariańskiej funkcjonującej w szkole bazyliańskiej w Podubisiu dotyczyły głównie składu władz kongregacji oraz liczby sodalisów w latach 1801-1822. Zarząd sodalicji tworzyli: prefekt, wiceprefekt, prefekt nowicjuszy, sekretarze, asystenci, radcy, mówcy publiczni, noszący obraz, usposabiający do sodalistwa, odwiedzający chorych, zakrystianie, chorążowie, marszałkowie. Na przestrzeni lat zmieniała się liczba osób wybieranych na określone stanowiska. Tylko funkcje prefekta, wiceprefekta i prefekta nowicjuszy były pełnione jednoosobowo. Pozostałe tworzyły grona od 2 do 12 osób. Na urząd mówcy publicznego wybierano zawsze dwie osoby, z których jedną określano jako „chwalcę Niepokalanego Poczęcia Maryi Panny, zaś drugiego jako chwalcę św. Onufrego" 58 .

Tabela 2. Liczba sodalisów w szkole bazyliańskiej w Podubisiu w latach 1801-1821

\begin{tabular}{|c|c|c|c|}
\hline Rok & Liczba sodalisów & Czlonkowie wladz & Pozostali sodalisi \\
\hline 1 & 2 & 3 & 4 \\
\hline 1801 & 90 & 62 & 28 \\
\hline 1803 & 87 & 62 & 25 \\
\hline 1804 & 82 & 65 & 17 \\
\hline 1805 & 91 & 65 & 26 \\
\hline 1806 & 111 & 70 & 41 \\
\hline 1807 & 75 & 54 & 21 \\
\hline 1808 & 86 & 51 & 35 \\
\hline 1809 & 85 & 50 & 35 \\
\hline 1810 & 80 & 46 & 34 \\
\hline 1811 & 100 & 49 & 51 \\
\hline
\end{tabular}

${ }^{57}$ J.M. Giżycki (Wołyniak), Bazylianie na Żmudzi, Kraków 1891, s. 5-27; Słownik geograficzny Królestwa Polskiego i innych krajów stowiańskich, t. VIII, Warszawa 1887, s. 475; Raporty generalnych wizytatorów szkót Komisji Edukacji Narodowej w Wielkim Księstwie Litewskim (1782-1792), opr. K. Bartnicka, I. Szybiak, Wrocław-Warszawa1974, s. 86, 114.

${ }^{58} \mathrm{BCz}$, rkps 1943, s. 74-141. 


\begin{tabular}{|c|c|c|c|}
\hline 1 & 2 & 3 & 4 \\
\hline 1812 & 77 & 59 & 18 \\
\hline 1813 & 118 & 77 & 41 \\
\hline 1814 & 114 & 56 & 58 \\
\hline 1815 & 169 & 63 & 106 \\
\hline 1816 & 177 & 48 & 129 \\
\hline 1817 & 200 & 62 & 138 \\
\hline 1818 & 204 & 61 & 143 \\
\hline 1819 & 179 & 63 & 116 \\
\hline 1820 & 199 & 74 & 125 \\
\hline 1821 & 160 & 63 & 97 \\
\hline
\end{tabular}

Źródło: BCz, rkps 1943, s. 74-141.

Kolegium bazyliańskie w Humaniu, funkcjonujące od ufundowania w 1766 r. klasztoru i cerkwi w tym mieście przez generała ziem kijowskich Franciszka Salezego Potockiego, miało w swej historii momenty tragiczne. Takim był rok 1768, w którym w wyniku okrutnej rzezi dokonanej przez oddziały Iwana Gonty i Maksyma Żeleźniaka zginęli bazylianie i uczniowie szkoły humańskiej. Na początku lat siedemdziesiątych XVIII w. kolegium wznowiło działalność, zaś pod koniec 1789 r. przeniesiono naukę do nowego, murowanego budynku ${ }^{59}$. Tamtejsza Sodalicja Mariańska, pozostająca pw. Opieki NMP, powstała najprawdopodobniej zaraz po otwarciu szkoły, ale po wydarzeniach $1768 \mathrm{r}$. ponownie postarano się o uzyskanie dla jej członków odpustów papieskich z okazji świąt maryjnych. Odpowiedni przywilej wystawił 12 XII 1773 r. papież Klemens XIV. Na jego mocy szczególne łaski można było uzyskać przystępując do sakramentów św. w następujące święta maryjne: Zwiastowanie (25 III), Oczyszczenie (2 II), Narodzenie (8 IX), Wniebowzięcie (15 VIII) i Niepokalane Poczęcie NMP (8 XII), a także w święta: śś. Apostołów Piotra i Pawła (29 VI), Podwyższenia Krzyża Św. (14 IX) oraz św. Mikołaja (6 XII) ${ }^{60}$. O kongregacji studenckiej wspominano także w aktach klasztornych w 1781 r., zaś 6 XII 1789 r. przeniesiono podczas podniosłej uroczystości obraz Matki Bożej słynący łaskami do nowo poświęconej siedziby sodalicji ${ }^{61}$.

${ }^{59}$ Biblioteka Jagiellońska w Krakowie (dal. cyt. BJ), rkps 4502-Rękopism klasztorny XX. Bazylianów humańskich z ostatnich czasów przed kasatą w r. 1832, k. 116v. Z tego rękopisu korzystał J. M. Giżycki (Wołyniak), O bazylianach w Humaniu, „Przewodnik Naukowy i Literacki”, 27 (1899) s. 852-853.

${ }^{60}$ Analecta Ordinis Sancti Basilii Magni, series II, sectio III: Audientiae Sanctissimi de rebus Ucrainae et Bielarusjae (1650-1850), vol. I: 1658-1779, coll. P. Athanasius G. Welykyj, Romae 1963, s. 173-174, nr 159. Starania o uzyskanie przywileju podjął o. Filaret Moczarski w 1774 r. prefekt szkół humańskich i profesor filozofii (IV klasa). Zob. Komisya Edukacyi Narodowej i jej szkoły w Koronie 1773-1794, z. 24: Raporty generalnych wizytatorów z r. 1774, wyd. T. Wierzbowski, Warszawa 1906, s. 116-117. Według J. M. Giżyckiego (Wołyniaka), O bazylianach w Humaniu, s. 946 sodalicja w szkole humańskiej pozostawała pod patronatem św. Jana Chrzciciela.

${ }^{61} \mathrm{BJ}$, rkps 4502, k. 116v. 
Kongregacja Mariańska działała również w jednej z najstarszych na terenie Rzeczypospolitej szkół ruskich we Włodzimierzu Wołyńskim. Tamtejsi bazylianie przejęli prowadzenie szkoły przy katedrze unickiej, na co uzyskali przywilej króla Augusta III w 1746 r. i Stanisława Augusta Poniatowskiego w 1768 r. ${ }^{62}$ Według wizytacji szkół włodzimierskich, przeprowadzonej przez wizytatorów Komisji Edukacji Narodowej w maju 1782 r., sodalicja nadal funkcjonowała. Jej istnienie oraz brak wprowadzenia zarządzeń Komisji w procesie nauczania były powodem krytyki podjętej ze strony wizytatorów ${ }^{63}$.

W 1781 r. bazylianie przejęli kolegium pojezuickie w Barze. W 1774 r. wizytatorzy Komisji Edukacji Narodowej opisali budynek szkolny jako murowany, dwukondygnacyjny, ale pośpiesznie wykończony, co skutkowało zapadnięciem się dachu. Na wyższym piętrze znajdowała się kongregacja, czyli oratorium, będąca też salą klasy retoryki ${ }^{64}$. W 1783 r. kontynuowano działalność Sodalicji Mariańskiej pozostającej pw. Niepokalanego Poczęcia NMP, o której wzmiankowano w 1755 r. Jej członkowie składali się corocznie po 1 złp na świece służące uświetnieniu nabożeństw kongregacji. Co roku odbywała się też elekcja władz i rozrachunek z prowadzonych wydatków ${ }^{65}$.

W raporcie z 1783 r. przedstawiciel Komisji Edukacji Narodowej wizytujący kolegium bazyliańskie w Szarogrodzie odnotował funkcjonowanie wśród tamtejszej społeczności szkolnej Kongregacji Mariańskiej ${ }^{66}$. Najprawdopodobniej założono ją w niedługim czasie po uruchomieniu tamtejszego kolegium, o którym wzmianki pochodziły już z $1748 \mathrm{r}$. W tym czasie wśród tamtejszych zakonników byli wymieniani prefekt szkoły, a równocześnie profesor syntaksy i poetyki oraz profesor gramatyki ${ }^{67}$.

Sodalicja Mariańska pw. Niepokalanego Poczęcia NMP działała w 1782 i 1783 r. w kolegium bazyliańskim w Lubarze w województwie wołyńskim. Tamtejszy monaster nieznanej fundacji został w 1666 r. otoczony opieką Lubomir-

${ }^{62}$ Archiv Jugo-Zapadnoj Rossii, izdavamyj Vremennoju Komissieju dlja razbora drevnich aktov, vysočajše učreždennoju pri Kievskom voennom, Podolskom i Volynskom General-Gubernatore, č. I, t. IV, Kiev 1871, nr CXCIX, s. 458-460.

${ }^{63}$ J. M. Giżycki (Wołyniak), Bazylianie we Włodzimierzu i Tryhorach, Kraków 1912, s. 62.

${ }^{64}$ Komisya Edukacyi Narodowej i jej szkoły w Koronie 1773-1794, z. 24, s. 47.

${ }^{65}$ Komisya Edukacyi Narodowej i jej szkoły w Koronie 1773-1794, z. 26: Raporty generalnych wizytatorów z r. 1783 Bonifacego Garyckiego i Franciszka Kolendowicza, wyd. T. Wierzbowski, Warszawa 1910, s. 66, 92-93; J. Flaga, Działalność duszpasterska zakonów w drugiej połowie XVIII wieku, Lublin 1986, s. 215.

${ }^{66}$ Komisya Edukacyi Narodowej i jej szkoły w Koronie 1773-1794, z. 26, s. 68, 92-93.

${ }^{67}$ PAOT, f. 258, op. 3, sp. 1254, k. 236v. Fundacja monasteru w Szarogrodzie została podpisana przez Stanisława Lubomirskiego we Lwowie 13 I 1749 r. Archiv Jugo-Zapadnoj Rossii, č. I, t. IV, nr CCIII, s. 473-475. Według J. M. Giżyckiego (Wołyniaka), Z przeszłości Zakonu Bazyliańskiego na Litwie i Rusi, „Przewodnik Naukowy i Literacki”, 32 (1904) s. 456-457 początkowo szkoła dla młodzieży świeckiej miała charakter szkółki parafialnej i dopiero około $1780 \mathrm{r}$. jej status podniesiono do rangi placówki podwydziałowej. Jednak domniemywać można z racji występowania w latach 1748-1754 dwóch lub trzech profesorów wyższego niż parafialny stopnia organizacji szkoły. 
skich. W 1752 r. szkoła lubarska składała się z izby z alkierzem. W latach osiemdziesiątych XVIII w. potrzebowała ona reperacji ${ }^{68}$.

Funkcjonowanie Sodalicji Mariańskiej w placówkach podległych Komisji Edukacji Narodowej w latach osiemdziesiątych XVIII w. było krytykowane przez wizytatorów odwiedzających szkoły. Ks. Szczepan Hołowczyc, który w 1782 r. zwizytował wydziały szkolne w południowo-wschodniej Rzeczypospolitej odnotował, że kongregacje, czyli sodalistwa wydają się być fundamentem ćwiczenia w pobożności. W spostrzeżeniach powizytacyjnych odnotował: „Trzeba koniecznie uczynić jakoweś umiarkowanie w przydatkowem nabożeństwie Sodalitatis Marianae w szkołach pojezuickich, pijarskich i bazyliańskich praktykowanej, którą takoż zwykli nazywać kongregacyją. To nabożeństwo podług dawnego zwyczaju wyciąga trochę podatku, elekcyi prefektów i innych ceremonij, za któremi następują czasem inkonwenijencyje. Sądziłbym tę pobożność zamienić (jeśli koniecznie pragną tych kongregacji) w towarzystwo miłosierdzia, ogniwem cnoty i wzajemnego wspomożenia spojone" ${ }^{69}$. Również wizytatorzy generalni odwiedzający szkoły położone na ziemiach polskich w $1783 \mathrm{r}$. w swoim raporcie zaznaczyli: „Kongregacye czyli sodalitates według opisu szczególnego i wiadomości pobocznej bywają z znacznemi składkami tak przez uczniów, jako i przez obywatelow w niektórych miejscach; możnaby te sodalitatos albo reformować, albo tak rozporządzić, aby z nich cząstka na ubogich studentów i chorych potrzebnych dostała się"70. Protokoły posiedzeń Komisji Edukacji Narodowej nie zawierały jednak żadnych informacji na temat zmian w działaniu Sodalicji Mariańskiej ${ }^{71}$.

W 1803 r. zwierzchnik bazyliańskiej prowincji Opieki NMP o. Florian Szaszkiewicz stwierdził, że oto dawny zwyczaj kongregacyi po wszystkich naszych szkołach byt praktykowany ${ }^{72}$. Zatem również w placówkach prowadzonych przez zakon św. Bazylego Wielkiego Sodalicja Mariańska stanowiła składnik procesu dydaktyczno-wychowawczego. Organizowana była na tych samych zasadach co kongregacje $\mathrm{w}$ kolegiach jezuickich. Występowała w ośrodkach, które założone zostały w XVII lub pierwszej połowie XVIII w., albo w szkołach przejętych z rąk jezuitów. Bazylianie doprowadzali wówczas do ponownego uruchomienia organizacji powołując się na wcześniejszą tradycję. Nie udało się natomiast odnaleźć śladów funkcjonowania Sodalicji Mariańskiej w szkołach publicznych zorganizowanych pod koniec XVIII wieku na ziemiach polskich zabranych przez Austrię, jak np. w placówkach w Drohobyczu czy Ławrowie. Na przeszkodzie powołania tam sodalicji stały szerząca się $\mathrm{w}$ tym czasie na ziemiach polskich ideologia

${ }^{68}$ Wisłocki, Ks. Szczepana Hołowczyca raport, s.47; Komisya Edukacyi Narodowej i jej szkoły w Koronie 1773-1794, z. 26, s.71, 94-95; PAOT, f. 258, op. 3, sp. 1254, k.126-126v; J. M. Giżycki (Wołyniak), Spis klasztorów unickich bazylianów w województwie wołyńskiem, Kraków 1905, s. 49-50.

${ }^{69}$ Wisłocki, Ks. Szczepana Holowczyca raport, s. 58-59.

${ }^{70}$ Komisya Edukacyi Narodowej i jej szkoły w Koronie 1773-1794, z. 26, s. 82.

${ }^{71}$ Protokoty posiedzeń Komisji Edukacji Narodowej 1773-1785, opr. M. Mitera-Dobrowolska, Wrocław-Warszawa 1973; Protokoły posiedzeń Komisji Edukacji Narodowej 1786-1794, opr. T. Mizia, Wrocław-Warszawa 1969.

${ }^{72} \mathrm{BJ}$, rkps 4502, k.33. 
oświeceniowa, a przede wszystkim polityka religijna monarchii habsburskiej, niechętna brackim formom pobożności. Jej przejawem był patent Józefa II z $22 \mathrm{~V}$ 1783 r. kasujący bractwa kościelne ${ }^{73}$. Również stosunek Komisji Edukacji Narodowej do działalności kongregacji w szkołach pozostających pod jej nadzorem był negatywny. Sodalicję postrzegano jako organizację o charakterze dewocyjnym, której członkowie marnotrawili fundusze na wystawne zebrania i nabożeństwa, zamiast skoncentrować się na działalności użytecznej społecznie.

Analiza zapisów w księgach prowadzonych przez sodalisów w kolegiach w Buczaczu, Owruczu i Podubisiu, a rejestrujących zebrania kongregacji, elekcje władz, spisy członków organizacji, czy też jej majątek pozwalały stwierdzić, że działalność Sodalicji Mariańskiej była świadectwem pobożności młodzieży kształcącej się w szkołach bazyliańskich oraz przygotowywała uczniów do życia publicznego poprzez zdobywanie doświadczenia oratorskiego. Mimo że w ostatniej ćwierci XVIII w. kongregacje były traktowane jako przejaw religijności potrydenckiej, kojarzonej z barokową skłonnością do przerostu zewnętrznych form, nie przystającej do potrzeb czasu, to jednak przetrwały okres oświeceniowych zmian i w XIX w. odrodziły się ponownie, zajmując ważne miejsce wśród stowarzyszeń skupiających młodzież uczącą się i studiującą.

\title{
THE ACTIVITY OF THE SODALITY OF OUR LADY IN BASILIAN COLLEGES IN THE TERRITORY OF THE POLISH REPUBLIC IN THE 18TH AND THE 19TH CENTURIES.
}

\begin{abstract}
Summary
The aim of this article is to present the activity of the Sodality of Our Lady functioning in public secondary schools run by the Basilian Order in eastern Poland in the 18th and the 19th centuries. The sources of the information were the books of the congregation, inventories of the monasteries and educational records stored in Polish and Ukrainian archives and printed reports of school visitations conducted by the Commission of National Education. We managed to find traces of the activity of the Sodality of Our Lady in 10 Basilian colleges, out of 20 functioning in the 18th century in the Polish-Lithuanian State. The activity of three schools- Buczacz, Owrucz and Podubiś- is the best documented one in sources. As far as the organizational pattern is concerned, these congregations followed the example of societies functioning in the colleges run by Jesuits. The students of the Sodality were distinguished by very good results in learning, impeccable behavior and devotion. The Marian Congregation helped to deepen faith and they paid special attention to the cult of Mary. They also prepared young people from the gentry background to take part in public life. The Congregation was a very important element in the educational process conducted in the public monastic schools.
\end{abstract}

Translated by Aneta Kiper

${ }^{73}$ T. Śliwa, Kościół greckokatolicki w zaborze austriackim (1772-1815), w: Historia Kościoła w Polsce, red. B. Kumor, Z. Obertyński, t. II, cz. 1, Poznań-Warszawa 1979, s. 298. 